\title{
Kemény Feri halálára
}

Nekem is nehéz emlékező, méltató búcsúszavakat találni - mert nehéz búcsúzni Feritől! Hosszan tartó betegsége ellenére is váratlan halála annyira megrázott, mint ahogyan egy jó barát, kolléga, egy, az életünkben fontos ember elvesztése mindannyiunk számára ismerősen fájdalmas hiányérzést okoz!

Jó arra gondolni ugyanakkor, hogy nagyon sokan vannak, akik ugyanígy átérzik a veszteséget, hiszen nagyon sokan ismerték és kerültek Feri bủvkörébe, így majd olvasva emlékező soraimat, ki fogják egészíteni a sajátjaikkal.

A megjelenés fontos a felidézésében. Egy viszonylag nagy ember, pocak, nagy, barna és mindig mosolygós szemek, és valami hamiskás, kedves megjegyzés, amitől jobban érezték magukat az emberek körülötte.

Népszerü tanár volt, és népszerü szakmaszervező. Integratív személyiség, akinek a kedvéért jobb szakemberek lettek az általa tanítottak, és jobban dolgoztak a terepen dolgozók. Ezt egyszerüen úgy érte el, hogy míg tényleg könnyed és kedves volt, a szakmát nagyon szerette, ismerte, és komolyan vette.

Bár már az 1970-es évek második felében is ismertük egymást, amikor óraadóként tanítottam a szociális szervező képzésben, mélyebben a 80 -as évek végén kerültünk munkakapcsolatba egymással. Ekkor, 1987-ben, fóálásba hívott tanítani a szakra. Mivel addigra már elköteleztem magam az ELTE szociálpolitikai képzésében, ezért az azóta kedves kollégámmá vált Szabó Lajos lépett be a tanszékre. Így érthető is, hogy együtt igyekszünk megidézni Feri emlékét.

Ezek a 80-as évek a mi generációnk legizgalmasabb, valóban sorsfordító időszakát jelentik. Reformidőszak volt. A politikai vezetés a rendszer egészét meg akarta reformálni. Ezen belül fogalmazódott meg a szociálpolitika reformjának az igénye, aminek részeként pedig a szociális munkás képzés bevezetésének a szükségessége. Sokszor tárgyaltuk már ezt az időszakot, de itt is megkerülhetetlen Kemény Ferenc szerepének említése a folyamatok megértése érdekében.

$\mathrm{S}$ az én életem itt kapcsolódott össze Feriével, a mai napig ható erővel. A 80-as évek elején ugyanis Talyigás Katival lehetőségünk volt részt venni a Ferge Zsuzsa irányításával zajló, a szociálpolitika reformját előkészíteni hivatott kutatásban. Ennek keretében, sok más kollégánk részvételével, végeztünk egy empirikus és irodalmi kutatást a magyar szociálpolitika hiányzó láncszemének, a személyi szolgáltatást végző szociális munkások felsőfokú képzésének bevezetésére, és ez bekerült a reformanyag ajánlásai közé. Nekem ekkor sikerült egy ausztrál ösztöndíjat megpályázni, és a megszerzett szociális munka mesterdiplomával érkeztem haza 1987-ben. A diplomamunkámban igyekeztem megismerni és leírni az akkori szociális munkás képzések legmodernebb formáit a remélhetőleg egyszer megvalósuló magyar képzés számára. S lőn: 1988-ban megalakulnak az egyetemi, főiskolai és középszintű szociális munkás képzéseket előkészítő grémiumok, ahol rögtön hasznosítani tudtam a diplomámat. Erre mondják, hogy a véletlen mekkora szervező ereje az életnek, az éppen megírt és hazahozott diplomamunkámban leírt ,általános szociális munka” koncepciója vált az előkészítő grémiumok hivatalos szakmai ajánlásává a bevezetendő szociális munkás képzések tantervének alapjává. 
Ez volt az a pont, amikor a konfliktus elkerülhetetlennek látszott a Göllesz Viktor, illetve Kemény Ferenc nevével fémjelzett szociális szervező képzéssel. Ez a képzés ugyanis első diplomaként adott speciális végzettséget, szemben az általános koncepcióval, ami széles és általános alapozást nyújtott, olyat, ami önmagában is elegendő volt a szakmában való munkára (ez a mai BA végzettség), de lehetőséget adott későbbi specializációk megszerzésére is. A két koncepció vitájából végül az általános tantervi javaslat került elfogadásra, de már akkor látszott, hogy a szociális szervező képzés folytatható, de egy szinttel feljebb: egy majdani szociális intézményvezetői szakosító képzésben. A konfliktus feloldása oktatásszervezési szempontból tehát nem látszott nehéznek, de természetesen az emberi tényező ezt megnehezítette. Sajnos, Göllesz Viktor nehezen viselte a változást, pedig a szakma megújításában betöltött szerepét senki nem vitatta. Szerencsére, Kemény Feri ebben az esetben távlatosabban, és inkább az ügyre koncentrálva, az érthető sérelmek ellenére is emelkedettebben tudott viselkedni. Az általa nagyon szeretett és őszintén tisztelt Göllesz Viktorral ellentétben megértette, hogy az általános koncepció távlatosabb lehetőséget nyújt a szakma fejlődésének, és ugyanakkor nem megszünteti, hanem felemeli a szociális szervező képzést. Pedig veszteség Öt is érte. Amikor megalakult az Általános Szociálismunkás-képző Tanszék, abba beolvadt a szociális szervező képzés, ami aztán néhány év múlva meg is szünt.

Ebben a turbulens átalakuló időben kerültem magam a Főiskolára, 1992-ben. Végül az élet, a nagy rendező úgy hozta, hogy ettől kezdve kollégák lettünk Ferivel is, Lajossal is.

S ekkor megjelent az életünkben Suzanne Stanisiere Asszony, a strasbourgi Szociális Munkás Képző Főiskola nemzetközi ügyekért felelős tanára, aki a rendszerváltás eufóriájában egyike volt azoknak a nyugat-európai, nyitott gondolkodású kollégáknak, akik szerettek volna valami szakmailag értékelhetőt tenni a most induló kelet-európai képzésekért. A kapcsolat Szőnyi Magda pszichológusnak volt köszönhető, aki elhozta a Bárczira az egyébként szintén pszichológus kolléganőjét Illyés Sándorhoz, a föiskola főigazgatójához. Az ajánlatról ma is azt gondolom, hogy az élet ajándéka volt, aminek a neve „szociális menedzser szakirányú továbbképzési szak" volt! Éppen az, ami továbbképzési lehetőség ígéretét nyújthatta a majd néhány év múlva vezetői pozíció közelébe kerülő saját általános végzettségü hallgatóinknak, de egyben az akkor már terepen dolgozó, szociális intézményvezetőknek is. Most aztán Feri elemében volt, hiszen újra átélhette a szociális intézmények vezetőképzési tantervének kidolgozásával járó örömöket, vitákat, a felépítés reptető érzését, ráadásul francia barátaink és kollégáink hihetetlen sok segítségével. Párhuzamosan tanultunk és dolgoztunk. Időnként Pesten, aztán az időközben oktatási célra kialakított, s a nagyszerü Török Iván igazgatása alatt gyorsan felfejlődött salgótarjáni Népjóléti Képzési Központban, illetve 1-1 hetet Strasbourgban is, az ottani főiskola szaktanárainak ,diákjaiként”! Közben sikerült egy nagyszerü oktató gárdát szervezni, akiknek a segítségével kidolgoztuk a 3 éves képzés tantervét, és 1996-ban, a Milleneum évében kioszthattuk az első diplomákat is. A salgótarjáni képzés fogalom lett a szakmában, mert a képzések hetében, 5 napon keresztül ott laktak a hallgatók a kollégiumban, ami egy ma már elképzelhetetlenül intenzív tanulási és közösségfejlesztési hatású felnőttoktatást tett lehetővé. Oda jártunk le 1 napos órákat tartani. Kemény tanár úr fürdött a népszerüség melegében. Több volt szociális szervező hallgatója újra beiratkozott, most már a menedzser diplomáért, az abban kötelezően előírt egyhetes külföldi gyakorlatért, de Kemény tanár úr kedvéért is! A képzés addig folyt sikerrel jó másfél évtizeden keresztül, amíg a 
minisztérium el nem adta a salgótarjáni központot. Azóta minden megváltozott, de a szociális intézmények vezetőképzésének történetét Kemény Ferenc nélkül nem lehet megírni.

Szimbolikus, hogy utoljára talán három hónappal váratlan halála előtt Suzanne Stanisiere társaságában jártam nála. Jó volt együtt felidézni a kezdeteket, a sok kedves kollégát, a közös utakat, s akkor eszünkbe sem jutott, hogy hamarosan lecsap ránk a COVID-19 járvány, aminek, sajnos, Feri is egyik áldozata lesz!

Természetesen, Kemény Ferencnek helye van a Szociális Szakma Digitális Arcképcsarnokában, ahol fel tudjuk majd sorolni részletesen is szakmateremtő életmüvét, kollégáit és tanítványait.

Itt és most csak röviden tudtuk felvillantani kedves kollégánk és barátunk szerethető személyét, és szimbolikusan megemelhettük kalapunkat életteljesítménye előtt a magunk, de természetesen kollégái és tanítványai nevében is, akikkel együtt soha nem fogjuk elfelejteni!

Hegyesi Gábor 